\title{
Az időskori gyógyszerterápia alapjai
}

\author{
Telekes András dr. - Deme Dániel dr.
}

Szent Lázár Megyei Kórház, Onkológiai Osztály, Salgótarján

\begin{abstract}
A fejlett országokban mindinkább nő az idős személyek számaránya, ami odavezet, hogy az idős betegek gyógyszeres terápiája egyre fontosabb helyet foglal el az egészségügyben. Fontos biológiai változások jellemzik az idős egyének szervezetét, melyeknek kihatásuk van a gyógyszerek farmakokinetikájára és farmakodinámiájára is. A vesefunkció fokozatos beszúkülése a gyógyszeradagolás módosítását igényelheti. Bizonyos gyógyszerek és gyógyszer-interakciók potenciális veszélyt jelentenek ezen populáció számára. Ezért az idős betegek kezelése során számos faktort kell mérlegelni, beleértve a társbetegségeket, a kognitív funkciót és a szociális helyzetet is. Ugyanakkor a gyógyszerterápiában, ezen belül a polypragmasiában részesülő idősek esetén a legrosszabb a gyógyszerek kockázat-haszon aránya. Ennélfogva a geriátriai farmakoterápia fejlődéséhez elengedhetetlen, hogy az időskor fiziológiás változásait a napi gyakorlaton kívül már a gyógyszerfejlesztés és -kiszerelés megtervezése során is figyelembe vegyék. A jelen közlemény áttekinti az idős betegek gyógyszeres kezelését befolyásoló legfontosabb faktorokat.

Orv Hetil. 2019; 160(23): 896-907.
\end{abstract}

Kulcsszavak: geriátrai farmakoterápia, gyógyszeradagolás, kockázat-haszon arány

\section{Principles of pharmacotherapy in the elderly}

The proportion of elderly patients is getting increased in the developed countries as a consequence of which pharmacotherapy takes a more and more important place in the healthcare system. Important biological alterations are characteristic for the elderly subjects, which have effect on the pharmacokinetics and pharmacodynamics of the pharmaceuticals. Gradually decreased kidney function may demand the modification of the administration of the pharmaceuticals. Certain pharmaceuticals and drug-interactions are potentially dangerous for this population. Therefore several factors have to be taken into account in conjunction with the therapy of elderly patients including co-morbidities, cognitive function and the social state. At the same time, the risk-benefit ratio of the pharmaceuticals is the worst among elderly patients with pharmaceutical therapy including polypragmasy. Thus, it is inevitable for the development of geriatric pharmacotherapy that the physiologic alteration of elderly has to be taken into account not only in the daily practice but also during the development and formulation of a pharmaceutical. The present paper gives an overview of the most important factors influencing the pharmacotherapy of the elderly.

Keywords: geriatric pharmacotherapy, drug administration, risk-benefit ratio

Telekes A, Deme D. [Principles of pharmacotherapy in the elderly]. Orv Hetil. 2019; 160(23): 896-907.

(Beérkezett: 2019. január 3.; elfogadva: 2019. február 18.)

\section{Rövidítések}

AUC $=$ (area under the concentration-time curve) koncentráció-idő görbe alatti terület; $\mathrm{CI}=$ (confidence interval) konfidenciaintervallum; Cmax $=$ a maximális plazmakoncentráció nagysága; $\mathrm{DAO}=$ diamin-oxidáz; DNS = dezoxiribonukleinsav; $\mathrm{EKG}=$ elektrokardiográfia; GFR = glomerulusfiltrációs ráta; $\mathrm{HNMT}=$ hisztamin- $\mathrm{N}$-metil-transzferáz; $\mathrm{HR}=$ (hazard ratio) kockázati arány; HYVET $=($ HYpertension in the Very Elderly Trial) magyar neve; NADPH = nikotinamid-adenindinukleotid-foszfát; NSAID $=$ (nonsteroidal antiinflammatory drug) nemszteroid gyulladáscsökkentő gyógyszer; PIM = (potentially inappropriate medication) potenciálisan inadekvát me- dikáció; SPRINT $=($ Systolic blood PRessure INtervention Trial) magyar neve; tmax $=$ a maximális koncentráció elérési ideje; $\mathrm{WHO}=($ World Health Organization $)$ Egészségügyi Világszervezet

A társadalom elöregedését a gazdaság és az egészségügy szempontjából egyaránt krízishelyzetnek lehet tekinteni. Ennek magyarázata egyrészt az, hogy a fejlett országokban egyre nő az idős személyek számaránya. Másrészt, az idős betegek kezelése során számos faktort kell mérlegel- 
ni, beleértve a társbetegségeket (gyógyszer-interakciók, egyes terápiák ellenjavallatát képezhetik a társbetegségek), a kognitív funkciót (compliance), a szociális helyzetet (az idős betegek egy része anyagi okokból ki sem váltja az orvos által felírt receptet).

A geriátriai farmakoterápia paradoxonja, hogy a gyógyszerterápiában és ezen belül a polypragmasiában részesülő idősek esetén a legrosszabb a gyógyszerek kockázat-haszon aránya. Mi több, a klinikai vizsgálatokba az időseket, a beválasztási kritériumokban megszabott életkorhatárok miatt, rendszerint nem vonják be, így velük kapcsolatban áll rendelkezésre a legkevesebb terápiás evidencia. Végül, az oktatás során nem kap kellő hangsúlyt az idősödés természetes folyamatainak hatása a gyógyszerterápiára.

\section{Biológiai változások időskorban}

Az időskor egyik legfontosabb jellemzője a homeosztázis és a környezeti adaptáció romlása, ami önmagában is hajlamosít a betegségekre. Az öregedés élettani hátterében alapvető szerepet játszik az oxidatív stressz, a mitokondriumok funkcióromlása, a telomerek rövidülése, illetve egyes genetikai folyamatok, valamint a kalóriabevitel.

Az öregedés szabadgyök-elméletét 1956-ban vetették fel először. Számos evidencia igazolja, hogy az öregedéshez szabad gyökök okozta károsodás társul, de még mindig nem egyértelmú, hogy ez az öregedés kiváltó oka. Feltételezik, hogy a szabad gyökök károsító hatása magyarázza, hogy a magasabb metabolikus rátájú élőlényeknek rövidebb az élettartamuk. Reaktív szabad gyökök az élettani folyamatok során képződnek, mint például, a mitokondriumok múködésének melléktermékei, fagocitózis, prosztaglandinszintézis, citokróm P450 enzimek múködése, illetve külső behatások következményeként, mint például ionizáló sugárzás. A szervezetben azonban a szabad gyököktől védő mechanizmusok is vannak, mint például szuperoxid-dizmutáz, kataláz, glutation-peroxidáz, glutation-transzferázok, peroxidázok, tiolspecifikus antioxidáns enzimek, C-vitamin, glutation, $\beta$-karotin, $\alpha$-tokoferol, húgysav, bilirubin. Érdekes, hogy az is kiderült, hogy a reaktívoxigén-gyökök szerepet játszanak a sejtek fiziológiás szignálútjaiban.

A mitokondriumok egyszerre termelői és elszenvedői az oxidatív stressznek, ezért sokan gondolják, hogy a mitokondriumok fontos szerepet játszanak az öregedésben. A mitokondriális DNS akkumulálódó mutációit okozó reaktívoxigén-gyökök a légzési lánc melléktermékei, amelyek végső soron károsítják az elektrontranszfer-folyamatokat; ezt az ördögi kört sokan az öregedés alapjának tartják [1].

A normális (nem daganatos) sejtkultúrában a sejtek osztódási potenciálja limitált. Bizonyos számú osztódás után a sejtek az elöregedés jeleit mutatják, refrakterré válnak a mitogén szignálokra. Ez a folyamat megszabja az organizmusok élettartamának hosszát. A sejtöregedés egyik magyarázata a telomerek minden osztódás során
50-200 bázispárral megrövidülő hossza, amely ha elfogy, a sejt nem képes többé osztódni, és megindul az apoptózis folyamata. Az experimentális adatok azt igazolják, hogy az emberi fibroblastok maximális osztódási száma a donor életkorának függvénye. Mi több, számos korai öregedési kórképben (például Werner-szindróma) a szöveteket alkotó sejtek telomerek által megszabott „életkora” közelebb áll az idős emberekénél észleltekhez, mint amit az azonos életkorú egészséges egyéneknél észlelnek. A sejtosztódáson alapuló öregedéselmélet ellen szóló egyik legkomolyabb érv, hogy a nem osztódó sejteket tartalmazó agy esetén is ki lehet mutatni az öregedés jeleit. Bizonyos számú osztódás után a sejtekben beindul az apoptózis. Vannak, akik úgy gondolják, hogy az öregedés az apoptózis zavara, nevezetesen fokozódása. Az agyban is kimutatható az életkor előrehaladása során az apoptózisok számának fokozódása.

Korábban a DNS akkumulálódó sérüléseit az öregedés során észlelt szöveti funkcióromlás alapjának tekintették. Manapság ezt már nem tartják valószínünek. A legfontosabb ellenérv, hogy a múltban az organizmusok nem éltek elég hosszú ideig ahhoz, hogy az idős példányok evolúciós nyomás alatt álltak volna a programozott öregedés vagy éppen az öregedés elleni programok kialakulása vonatkozásában [2]. Mi több, a génexpresszió különböző a természetes öregedés és a korai öregedés esetén, illetve Drosophilában az öregedés okozta génexpresszió-változás és az oxidatív stressz okozta változás eltér egymástól [3].

A kalóriamegszorítás élesztőkben, Drosophilában, gilisztákban, rágcsálókban és feltehetően az emberben is meghosszabbítja az élettartamot. A tudományos kutatás azonban mindmáig nem tisztázta teljes mértékben a kalóriarestrikció élethosszabbító hatásmechanizmusát. A hipotézis az, hogy a csökkentett kalóriabevitel csökkenti a metabolikus rátát és így a reaktívoxigén-gyökök menynyiségét. Számos adat ismert azonban, amely nem egyeztethető össze ezzel az elmélettel. Például a denevéreknek és az egereknek azonos a metabolikus rátájuk, a denevérek mégis 10-szer hosszabb ideig élnek, mint az egerek [4].

\section{Az öregedés folyamatainak hatása a felszívódásra}

Az orális gyógyszerek vérbe jutásának aránya (bioavailability) számos faktor függvénye, mint például a gastrointestinalis nyálkahártyán átjutó gyógyszer mennyisége, ennek nem metabolizálódott aránya, illetve a májon történő áthaladás során metabolizálódó gyógyszermennyiség. Mindezekből számolható egy adott orális gyógyszer biológiai elérhetôsége, amely a tényleges terápiás hatást kifejti. Ezeket az arányokat számos egyéb faktor befolyásolja, mint például a gyomor $\mathrm{pH}$-értéke, a gastrointestinalis motilitás és véráramlás, a bélpermeabilitás, a gyógyszertranszporter molekulák mennyisége, a vékonybél felszínének nagysága (amely időskorban csökken). Az 
öregedés hatása ezekre a faktorokra a legtöbb esetben jól ismert, de ellentmondásos. Megint példaként említve, korábban úgy vélték, hogy a gyomor savtermelése csökken az öregedés során. Az újabb vizsgálatok azonban azt bizonyítják, hogy a kaukázusi populációban az idősek 5-10\%-a esetén valóban kimutatható a hypochlorhydria az atrophiás gastritis következményeként, a többség azonban megtartja normál savszekréciós képességét életének akár a tizedik évtizedében is [5]. Úgy tünik, a savszekréciós változások az életkor előrehaladása során sokkal inkább visszavezethetők az egyre elterjedtebb Helicobacter pylori-fertózésekre, illetve az időskorban gyakran használt protonpumpagátló és $\mathrm{H}_{2}$-receptor-antagonista-terápiákra, mint az öregedés természetes folyamataira. Nyilvánvalóan, a savszekréció csökkenése vagy csökkentése azokat az orális gyógyszereket érinti a leginkább, amelyek savas környezetben ionizálódnak (például ketokonazol, ampicillin, vaskészítmények).

Az öregedés hatása a gastrointestinalis motilitásra jól ismert. Az időskor lelassult gyomorürüléssel, csökkent perisztaltikával és így elhúzódó vastagbéltranszport-idővel jár együtt, aminek elsődleges oka a beidegzést biztosító neuronok számának csökkenése. Ez jelentős hatást fejthet ki a gyógyszerek felszívódására, ami azonban csak a gyógyszerek tmax- (a maximális koncentráció elérési ideje) és Cmax- (a maximális plazmakoncentráció nagysága) értékeit befolyásolja, nem az AUC-t (koncentráció-idő görbe alatti terület). Ma úgy vélik, hogy az életkor előrehaladásával a passzív intestinalis permeabilitás nem változik a legtöbb molekulára nézve, azonban az aktív transzportot igénylő molekulák (például glükóz, kalcium, $\mathrm{B}_{12}$-vitamin stb.) átjutása a gastrointestinalis rendszer nyálkahártyáján csökken(het). Mindezek alapján a gyomor-bél motilitás időskori változásai azokat a gyógyszereket érintik elsősorban, amelyek permeabilitása és oldékonysága alacsony. A magas permeabilitású gyógyszerek felszívódása elsősorban a gastrointestinalis véráramlás függvénye, amely - úgy tû́nik - időskorban csökken.

Az abszorpciót követően egyes gyógyszerek már a bélfalban metabolizálódnak, mások a májba jutva (ez a "firstpass" metabolizmus, amely azelőtt történik, hogy a gyógyszer a szisztémás keringésbe jut). A bélfali metabolizmus elsősorban azoknál a gyógyszereknél fordul elő, amelyek szubsztrátjai a CYP3A4 enzimnek, illetve a Pglikoproteinnek, mely utóbbi a sejtből kifelé irányuló transzportért felelős. Ennek elsősorban a gyógyszer-interakciók szempontjából van jelentősége, azonban a bélfal a helye az étel-gyógyszer interakcióknak is [6]. Az öregedés hatása az intestinalis gyógyszer-metabolizmusra nem ismert, joggal feltételezhető azonban, hogy jelentős szerepet játszik a polypragmasia okozta problémákban. Végül a felszívódás szempontjából fontos megemlíteni, hogy a bélben lévő baktériumok is részt vehetnek a gyógyszerek bélben történő metabolizmusában.
Az időskor hatása a gyógyszer-metabolizmusra - úgy tünik - gyógyszerfüggő, mivel például a lidokain, verapamil, labetolol, propranolol biohasznosulása majdnem megduplázódik, az imipramin, amitriptilin, morfin, metoprolol vagy meperidin értékei nem változnak, míg a levodopa esetén ez csökken.

\section{Az öregedés folyamatainak hatása a megoszlási volumenre}

Mindent egybevetve, az időskorban észlelt fehérjekötésváltozás nem jelentős klinikai szempontból. A vér albuminkoncentrációja hozzávetőleg 10\%-ot csökken időskorban, illetve feltételezik, hogy az $\alpha$ l-savas glikoprotein szintje emelkedik, elsősorban az időskori gyulladásos betegségek következtében [7]. Az albumin szintjének csökkenése miatt nőhet a szabad gyógyszerszint egyes gyógyszerek esetén, mint például a diazepám. Más gyógyszerek esetén ez nem változik, mint például a warfarin, prazozin. A terápiás hatékonyság szempontjából a szabad gyógyszerek AUC-értékei a mérvadók, és ezek a legtöbb gyógyszer esetén nem változnak szignifikánsan. Mint mindig, ez esetben is vannak kivételek, nevezetesen azok a gyógyszerek, amelyek nagymértékben extrahálódnak a májban, magas arányban kötődnek a fehérjékhez, illetve intravénás adagolásban kapják a betegek, mint például haloperidol, fentanil, propranolol, propofol, verapamil, lidokain, doxorubicin, midazolám [8].

$\mathrm{Az}$ öregedés egyéb olyan folyamatokkal is jár, amelyek hatással lehetnek a megoszlási volumenre. Idősek esetén a testzsír aránya 20-40\%-kal növekszik, a test víztartalma 10-15\%-kal csökken a korábbiakhoz képest [9]. Ezek a változások a vízoldékony gyógyszerek fokozott koncentrációját, illetve a lipidoldékony gyógyszerek megnövekedett eliminációs idejét okozzák. Ennek alapján parenteralis adagolás során a lipofil gyógyszerek úgynevezett feltöltő (loading) dózisát 10-20\%-kal növelni, míg a hidrofil gyógyszerek dózisát ugyanilyen mértékben csökkenteni kellene. A terápiában azonban ezek elmaradása nem feltétlenül okoz változást az eredményességben.

\section{$\mathrm{Az}$ öregedés folyamatainak hatása a májra és a gyógyszer-metabolizmusra}

Az in vivo vizsgálatok azt mutatják, hogy a gyógyszerek és más anyagok máj által történt eliminációja a máj véráramlásától, az úgynevezett belső clearance-tôl (a máj tömegének és enzimaktivitásának függvénye), illetve az adott anyag proteinkötési képességétől függ. A nagymértékben eliminált gyógyszerek eltávolítása lényegében csak a véráramlás függvénye, míg a máj által kevésbé eliminált gyógyszerek eltávolítása döntően a belső clearance-től, azaz a metabolikus kapacitástól, kisebb részben a proteinkötéstől függ. Az öregedés során csökken a máj véráramlása mintegy $40 \%$-kal, illetve a máj tömege is kevesebb lesz. Ugyanakkor az öregedés nem okoz kimutat- 
ható változásokat a máj mikroszomálisfehérje-tartalmában, vagy a NADPH, illetve a citokróm P450 enzimek aktivitásában [10] A gyógyszer-metabolizáló citokróm enzimek vonatkozásában azonban vannak az öregedés során csökkenésre utaló adatok is [11]. További érdekes adat, hogy egy vizsgálat alapján $(\mathrm{n}=226)$ azt találták, hogy az antipirinclearance 29\%-kal, a citokróm P450 mennyiség 32\%-kal csökkent a májbiopsziás minták vizsgálata alapján az életkor előrehaladásával. Azonban a citokróm P450 enzimek mennyiségének csökkenése előtt néhány évtizeddel korábban már kimutatható volt az antipirinclearance csökkenése [12]. Nevezetesen, a citokróm P450 mennyisége 40 és 69 év között nem változott, majd 70 éves kortól csökkent, míg az antipirinclearance 40 éves korig nem változott, de utána 0,34 $\mathrm{ml} \cdot \mathrm{min}^{-1}$ /év rátával csökkent az öregedés során, ami azt mutatja, hogy a gyógyszerclearance-csökkenés elsődleges oka nem a máj metabolikus kapacitásának csökkenése. Mi több, állatkísérletekben megpróbáltak biomarkereket keresni az öregedésre vonatkozóan normális táplálkozás, illetve kalóriabevitel megszorítása esetén egyaránt [13]. A vizsgálat azt igazolta, hogy az öregedés fenotípusa nagymértékben betegségek következménye. $\mathrm{Az}$ adatok részletesebb elemzése azt igazolta, hogy hímeken az öregedésre, illetve a kalóriamegszorításra vonatkozó 11 használható marker közül 6 kapcsolatot mutatott a májpatológiával.

\section{$\mathrm{Az}$ öregedés folyamatainak hatása a vesefunkciókra és gyógyszer-eliminációra}

A glomerulusfiltrációs rátának (GFR) az életkor előrehaladásával történő csökkenése az egyik legfontosabb változás, amely időskorban befolyásolja a farmakokinetikai változásokat. Az idős betegek esetén szükséges dózismódosításokat a Cockcroft-Gault-egyenlet segítségével lehet kiszámítani. Az egyenlet a vesefunkciót legjobban tükröző GFR becsült számítása, mivel a 24 órás gyưjtött vizeletből mért kreatininclearance pontatlan, az izotópclearance-vizsgálat pedig rutinszerú alkalmazásra túl bonyolult. A GFR értéke azért fontos, mert az idült vesebetegség a lakosság 10\%-át érinti, és a betegek többségének vesefunkciója is beszúkült. Klinikai szempontból elsősorban azoknál a gyógyszereknél kell a vesefunkció figyelembevételével kalkulálni a dózist, amely készítmények esetén eleve ajánlott a terápiás gyógyszerszint monitorozása a keskeny terápiás index miatt (gentamicin, digoxin, lítium). A Cockcroft-Gault-egyenlet a következő:

Kreatininclearance
$(\mathrm{ml} /$ perc $)=$ \begin{tabular}{c}
$\left(\begin{array}{c}140-\text { életkor }) \times \\
\text { testsúly }(\mathrm{kg})\end{array}\right.$ \\
\cline { 2 - 2 } $\begin{array}{c}72 \times \begin{array}{c}\text { szérumkreatinin } \\
(\mathrm{mg} / \mathrm{dl})\end{array} \\
\text { esetén }]\end{array}$
\end{tabular}

Idős betegeknél a napi kreatinintermelés csökkenését a csökkent izomtömeg magyarázza. A kreatininclearance ezért alábecsülheti a vesefunkciót, amit az igazol, hogy a gyógyszer farmakokinetikája nem változik [14]. Ugyancsak befolyásolhatja az eredményt, hogy az idősek fizikai aktivitása is csökken. Mi több, a GFR testfelszínre történő normalizálása tovább ronthatja a számítás eredményét idős betegek esetén [15].

Meg kell jegyezni, hogy a 65 év feletti lakosságra vonatkozóan a hypertonia prevalenciája $65 \%$, ami az öregedési folyamatoktól függetlenül befolyásolja a vesefunkciót. Mi több, vannak, akik úgy vélik, hogy a GFR életkori csökkenését inkább a betegségek okozzák, mint a normálöregedés.

Mindent egybevetve ma úgy látszik, hogy a GFR csökken az öregedés során, de nem olyan mértékben, ahogy azt korábban gondolták. Átlagban a GFR a középkor elérése után $1 \mathrm{ml} /$ perc/év rátával csökken, azonban az egészséges idősekben ez egyáltalán nem szükségszerü. Ez azt jelenti, hogy a Cockcroft-Gault-egyenlet lehet, hogy nem az öregedésból adódó GFR-változást mutatja, hanem az időskorban gyakrabban megjelenő vesebetegségeket. Ha ez igaz, akkor a Cockcroft-Gault-egyenlet használata az egészséges idősek esetén aluldozírozáshoz és így csökkent hatékonysághoz, míg elesett állapotú idősek esetén túldozírozáshoz és toxicitáshoz vezethet [16].

A fentebb leírtak szerepe a vesén át ürülő gyógyszerek kinetikájára vonatkozóan ugyancsak nem teljesen egyértelmü. Egy tanulmányban 101 geriátriai betegen végzett nyolc farmakokinetikai vizsgálat eredményeit analizálták [17]. Potenciálisan toxikus dózist 8 gyógyszer esetén észleltek (enalaprilát, cefotaxim, furoszemid, spironolakton, hidroklorotiazid, piracetám, pentoxifillin, lorazepám) akkor, ha a GFR becsült értéke kisebb volt, mint $40 \mathrm{ml} /$ perc. A magasabb kreatininclearance esetén valamennyi gyógyszer koncentrációja a terápiás tartományon belül volt. Ennek alapján a jelentős vesefunkció-romlás esetén a fenti 8 gyógyszer dóziscsökkentése javasolt. A vizsgálat egyúttal felhívja a figyelmet az idősek vizelethajtó terápiáinak veszélyeire.

Hasonlóképpen ellentmondásos a vese tömegének változása az életkorral összefüggésben. A korábbi közlemények szerint a vese tömege hozzávetőleg 20-25\%-kal csökken a 30-80 éves életkor között. A középkor elérése után a vese hosszúsága évtizedenként $0,5 \mathrm{~cm}$-t csökken. Másrészről, 175 egészséges, 17-85 éves önkéntes ultrahangos vizsgálata szerint a vese hossza mindössze 15\%kal csökken a 3. és a 9. évtized között [18].

Idős betegeknél a szérumkreatinin még a referenciatartományon belül lehet, miközben a vesefunkció már jelentősen károsodott. A Cockcroft-Gault-egyenlet használatának problémáira fentebb utaltunk, különösen elesett állapotú betegek esetén. Az 1. táblázatban megadjuk azoknak a legfontosabb gyógyszereknek a listáját, amelyek dózisát csökkent vesefunkció esetén módosítani kell. 
1. táblázat |A gyógyszerdózisok csökkentése veseelégtelenség esetén

\begin{tabular}{|c|c|}
\hline Gyógyszer & Dózismódosítás \\
\hline \multicolumn{2}{|l|}{$A C E-g a ́ t l o ́ k$} \\
\hline Benazepril & Clcr 10-30 ml/perc: kezdő dózis 2,5-5 mg naponta $1 \times$. A dózist a hatás függvényében módosítani kell. \\
\hline Kaptopril & $\begin{array}{l}\text { Clcr } 10-30 \mathrm{ml} / \text { perc: kezdő dózis } 12,5-25 \mathrm{mg} \text { naponta } 1 \times \text {. A dózist a hatás függvényében módosítani kell } \\
75-100 \mathrm{mg} / \text { nap dózisig. }\end{array}$ \\
\hline Cilazapril & $\begin{array}{l}\text { Clcr } 10-30 \mathrm{ml} / \text { perc: kezdő dózis maximum } 0,5 \mathrm{mg} / \text { nap. A dózist a hatás függvényében módosítani kell } \\
\text { maximum } 2,5 \mathrm{mg} / \text { nap dózisig. }\end{array}$ \\
\hline Enalapril & $\begin{array}{l}\text { Clcr 10-30 ml/perc: kezdő dózis maximum } 5 \text { mg/nap. A dózist a hatás függvényében módosítani kell } \\
\text { maximum } 10 \mathrm{mg} / \text { nap dózisig. }\end{array}$ \\
\hline Lizinopril & $\begin{array}{l}\text { Clcr 10-30 ml/perc: kezdő dózis maximum } 5 \mathrm{mg} / \text { nap. A dózist a hatás függvényében módosítani kell } \\
\text { maximum } 40 \mathrm{mg} / \text { nap dózisig. }\end{array}$ \\
\hline Perindopril & $\begin{array}{l}\text { Clcr 30-50 ml/perc: kezdő dózis maximum } 2 \mathrm{mg} / \mathrm{nap} \text {. Clcr 10-30 ml/perc: kezdő dózis maximum } 2 \mathrm{mg} \\
\text { kétnaponta. }\end{array}$ \\
\hline Kinapril & $\begin{array}{l}\text { Clcr } 30-50 \mathrm{ml} / \text { perc: kezdő dózis } 5 \mathrm{mg} / \mathrm{nap} \text {. Clcr } 10-30 \mathrm{ml} / \text { perc: kezdő dózis } 2,5 \mathrm{mg} \text { két/nap. A dózist a hatás } \\
\text { függvényében módosítani kell. }\end{array}$ \\
\hline Ramipril & $\begin{array}{l}\text { Clcr 20-50 ml/perc: kezdő dózis maximum 1,25 mg/nap. A dózist a hatás függvényében módosítani kell. } \\
\text { Clcr } 10-20 \mathrm{ml} / \text { perc: nincs adat terápiás ajánláshoz. }\end{array}$ \\
\hline Trandolapril & $\begin{array}{l}\text { Clcr 10-30 ml/perc: kezdő dózis maximum 0,5 mg/nap. A dózist a hatás függvényében módosítani kell } \\
\text { maximum } 2 \mathrm{mg} / \text { nap dózisig. }\end{array}$ \\
\hline Zofenopril & $\begin{array}{l}\text { Clcr } 10-50 \mathrm{ml} / \text { perc: kezdő dózis maximum 7,5 mg/nap. A dózist a hatás függvényében módosítani kell } \\
\text { maximum } 15 \mathrm{mg} / \text { nap dózisig. }\end{array}$ \\
\hline \multicolumn{2}{|l|}{ Antibiotikumok } \\
\hline \multicolumn{2}{|l|}{ Cefalosporinok } \\
\hline Cefalexin & Clcr 10-50 ml/perc: az adagolási időintervallumot 12 óránként egyszer adott dózisra kell módosítani. \\
\hline Cefalotin & $\begin{array}{l}\text { Clcr } 50-80 \mathrm{ml} / \text { perc: } 2 \text { g } 6 \text { óránként; Clrc } 30-50 \mathrm{ml} / \text { perc: } 1,5 \text { g } 6 \text { óránként; Clrc 10-30 ml/perc: } 1 \mathrm{~g} \\
8 \text { óránként. }\end{array}$ \\
\hline Cefamandol & $\begin{array}{l}\text { Clcr } 50-80 \mathrm{ml} / \text { perc: } 2 \mathrm{~g} 6 \text { óránként, életveszélyes infekció esetén 1,5 g } 4 \text { óránként; Clcr } 30-50 \mathrm{ml} / \mathrm{perc}: 2 \mathrm{~g} \\
8 \text { óránként, életveszélyes infekció esetén } 1,5 \mathrm{~g} 6 \text { óránként; Clcr } 10-30 \mathrm{ml} / \text { perc: } 1,25 \mathrm{~g} 6 \text { óránként, életveszélyes } \\
\text { infekció esetén } 1 \mathrm{~g} 6 \text { óránként. }\end{array}$ \\
\hline Cefazolin & Clcr 30-50 ml/perc: 500 mg 12 óránként; Clcr 10-30 ml/perc: 500 mg 24 óránként. \\
\hline Cefradin & Clcr<30 ml/perc: kontraindikált. \\
\hline Ceftazidim & Clcr 30-50 ml/perc: 1 g 12 óránként; Clcr 10-30 ml/perc: 1 g 24 óránként. \\
\hline Ceftibutén & Clcr 30-50 ml/perc: 200 mg 24 óránként; Clrc 10-30 ml/perc: 100 mg 12 óránként. \\
\hline Cefuroxim (parenteralis) & Clcr 10-30 ml/perc: standard dózis 12 óránként. \\
\hline \multicolumn{2}{|l|}{ Fluorokinolonok } \\
\hline Ciprofloxacin & Clcr $10-30 \mathrm{ml} /$ perc: a normáldózis $50 \%$-a. \\
\hline Levofloxacin; ofloxacin & Clcr $30-50 \mathrm{ml} /$ perc: a normáldózis $50 \%$-a. \\
\hline Norfloxacin & Clcr 10-30 ml/perc: a normáldózis 25\%-a. \\
\hline \multicolumn{2}{|l|}{ Karbapenem } \\
\hline Meropenem & Clcr 10-30 ml/perc: a dózisintervallum 24 óránként $1 \times$. \\
\hline \multicolumn{2}{|l|}{ Makrolid } \\
\hline Klaritromicin & $\begin{array}{l}\text { Clcr } 31-60 \mathrm{ml} / \text { perc: } 1 \text { g } 8 \text { óránként; Clcr 16-30 ml/perc: lg } 12 \text { óránként; Clcr } 5-15 \text { ml/perc: } 500 \text { mg } \\
24 \text { óránként. }\end{array}$ \\
\hline \multicolumn{2}{|l|}{ Nitrofurantoin } \\
\hline Nitrofurantoin & Clcr 10-30 ml/perc: a normáldózis 50\%-a, normál-dózisfrekvencia mellett. \\
\hline
\end{tabular}


1. táblázat folyt.

\begin{tabular}{|c|c|}
\hline Gyógyszer & Dózismódosítás \\
\hline \multicolumn{2}{|l|}{ Penicillinek } \\
\hline Ampicillin & Clcr $<50 \mathrm{ml} /$ perc: kontraindikált. Neuropathia, illetve hatástalan kezelés kockázata miatt. \\
\hline Amoxicillin/klavulanát & $\begin{array}{l}\text { Clcr } 31-60 \mathrm{ml} / \text { perc: } 2 \text { g } 6 \text { óránként; Clcr 16-30 ml/perc: } 2 \text { g } 6 \text { óránként; Clcr } 5 \text {-15 ml/perc: } 2 \text { g 6-8 } \\
\text { óránként. }\end{array}$ \\
\hline Benzilpenicillin & Clcr 10-30 ml/perc: standard dózis 12 óránként (orális, iv., im.). \\
\hline Piperacillin & Clcr 10-30 ml/perc: a dózis az indikáció függvénye, a túl- és aluldozírozás kockázatát mérlegelni kell. \\
\hline Piperacillin/tazobaktám & $\begin{array}{l}\text { Clcr 30-50 ml/perc: maximum } 12 \mathrm{~g} / \mathrm{nap} \text {, napi 3-4 dózisban. } \\
\text { Clcr 10-30 ml/perc: maximum } 8 \mathrm{~g} / \mathrm{nap} \text {, napi } 2 \text { dózisban. } \\
\text { Clcr } 30-50 \mathrm{ml} / \text { perc: piperacillin/tazobaktám } 12 \mathrm{~g} / 1,5 \mathrm{~g} \text { napi } 3-4 \text { dózisban; Clcr } 10-30 \mathrm{ml} / \text { perc: piperacillin } \\
4 \mathrm{~g} / 0,5 \mathrm{~g} 12 \text { óránként. }\end{array}$ \\
\hline Oxacillin & $\begin{array}{l}\text { Clcr } 31-60 \mathrm{ml} / \text { perc: } 2 \mathrm{~g} 4 \text { óránként; Clcr 16-30 ml/perc: 1-2 g 4-6 óránként; Clcr 5-15 ml/perc: } 1 \text { g 4-6 } \\
\text { óránként. }\end{array}$ \\
\hline \multicolumn{2}{|l|}{ Tetraciklin } \\
\hline Tetraciklin & Clcr 10-30 ml/perc: fenntartó dózis 250 mg naponta $1 \times$. \\
\hline $\begin{array}{l}\text { Antidiabetikumok } \\
\text { Metformin }\end{array}$ & Clcr 30-50 ml/perc: kezdő dózis 500 mg naponta 2×; Clcr 10-30 ml/perc: kontraindikált. \\
\hline $\begin{array}{l}\text { Szulfonilurea } \\
\text { (például tolbutamid) }\end{array}$ & Clcr<50 ml/perc: kezdő dózis a normál 50\%-a. \\
\hline
\end{tabular}

\section{Antibisztaminok}

Akrivasztin

Clcr 10-50 ml/perc: a normáldózis 50\%-a vagy a dózisintervallumok növelése napi 1-2-re.

Cetirizin; fexofenadin; hidroxizin; levocetirizin;

Clcr 10-50 ml/perc: a normáldózis 50\%-a.

terfenadin

\begin{tabular}{|c|c|}
\hline \multicolumn{2}{|l|}{ Antimikotikumok } \\
\hline Flukonazol & $\begin{array}{l}\text { Ha a dózisséma napi többszöri adagolás szerint történik, és Clrc 10-50 ml/perc: normál kezdő dózis után a } \\
\text { fenntartó dózisokat } 50 \% \text {-kal csökkenteni kell. }\end{array}$ \\
\hline Flucitozin & $\begin{array}{l}\text { Clcr } 30-50 \mathrm{ml} \text { /perc: dózisintervallum } 12 \text { óra, majd a terápiát a plazmakoncentrációra alapozva kell folytatni; } \\
\text { Clcr } 10-30 \mathrm{ml} \text { /perc: dózisintervallum } 24 \text { óra, majd a terápiát a plazmakoncentrációra alapozva kell folytatni. }\end{array}$ \\
\hline Terbinafin & Clcr $10-50 \mathrm{ml} /$ perc: a normáldózis $50 \%$-a. \\
\hline $\begin{array}{l}\text { Anti-Parkinson-szerek } \\
\text { Pramipexol }\end{array}$ & $\begin{array}{l}\text { Clcr } 30-50 \mathrm{ml} / \text { perc: kezdő dózis } 0,125 \mathrm{mg} 2 \times \text { naponta, majd hatás/mellékhatásokra alapozva; Clcr } 10-30 \mathrm{ml} / \\
\text { perc: kezdő dózis } 0,125 \mathrm{mg} 1 \times \text { naponta, majd hatás/mellékhatásokra alapozva. }\end{array}$ \\
\hline $\begin{array}{l}\text { Antitrombotikumok } \\
\text { Dabigatrán }\end{array}$ & Clcr $<30 \mathrm{ml} /$ perc: kontraindikált. \\
\hline Eptifibatid & Clcr 10-50ml/perc: normál kezdő dózis, majd a normáldózis 50\%-a. \\
\hline Tirofiban & Clcr 10-30 ml/perc: a normáldózis 50\%-a. \\
\hline $\begin{array}{l}\text { Antivivális szerek } \\
\text { Aciklovir (orális) }\end{array}$ & Clcr $10-30 \mathrm{ml} /$ perc: $800 \mathrm{mg} 3 \times$ naponta. \\
\hline Amantadin & $\begin{array}{l}\text { Kezdő dózis } 200 \mathrm{mg} \text {. Fenntartó dózis: Clcr } 50-80 \mathrm{ml} / \text { perc: } 100 \mathrm{mg} \text { naponta } 1 \times \text {; Clcr } 30-50 \mathrm{ml} / \text { perc: } 100 \mathrm{mg} \\
\text { másnaponta; Clcr } 10-30 \mathrm{ml} / \text { perc: } 100 \mathrm{mg} \text { háromnaponta. }\end{array}$ \\
\hline Cidofovir & Clcr<50 ml/perc: jobb másik szert alkalmazni. \\
\hline Famciklovir & Clcr 30-50 ml/perc: normáldózis 24 óránként; Clcr 10-30 ml/perc: normáldózis 50\%-a 24 óránként. \\
\hline Foszkarnet & Clcr 30-80 ml/perc: előírás szerint; Clcr <30 ml/perc: kontraindikált. \\
\hline Ganciklovir & $\begin{array}{l}\text { Indukció: Clcr } 50-80 \mathrm{ml} / \text { perc: a normáldózis } 50 \% \text {-a } 12 \text { óránként; Clcr } 30-50 \mathrm{ml} / \text { perc: a normáldózis } 50 \% \text {-a } 24 \\
\text { óránként; Clcr } 10-30 \mathrm{ml} / \text { perc: a normáldózis } 25 \% \text {-a } 24 \text { óránként. Fenntartó dózis: Clcr } 50-80 \mathrm{ml} / \text { perc: } \\
\text { a normáldózis } 50 \% \text {-a } 24 \text { óránként; Clcr } 30-50 \mathrm{ml} / \text { perc: a normáldózis } 25 \% \text {-a } 24 \text { óránként; Clcr } 10-30 \mathrm{ml} / \mathrm{perc} \text { : } \\
\text { a normáldózis } 12,5 \% \text {-a } 24 \text { óránként. }\end{array}$ \\
\hline
\end{tabular}


1. táblázat folyt.

\begin{tabular}{|c|c|}
\hline Gyógyszer & Dózismódosítás \\
\hline Oszeltamivir & Clcr 10-30 ml/perc: a normáldózis 50\%-a vagy a normáldózis dupla terápiás időintervallumokban. \\
\hline Ribavirin & Clcr 10-50 ml/perc: dozírozás a hemoglobinkoncentráció alapján. \\
\hline Valaciklovir & Clcr 10-80 ml/perc: dózismódosítás az alkalmazási előírás szerint. \\
\hline Valganciklovir & $\begin{array}{l}\text { Clcr } 30-50 \mathrm{ml} / \text { perc: a normáldózis } 50 \% \text {-a dupla terápiás időintervallumokban adva; Clcr } 10-30 \mathrm{ml} / \text { perc: } \\
\text { a normáldózis } 50 \% \text {-a hetente } 2 \times \text {. }\end{array}$ \\
\hline \multicolumn{2}{|l|}{$\beta$-receptor-gátlók } \\
\hline Acebutolol, atenolol & Clcr 10-30 ml/perc: a normáldózis 50\%-a. \\
\hline Bizoprolol & Clcr 10-20 ml/perc: kezdő dózis a normáldózis 50\%-a, majd maximum 10 mg/nap. \\
\hline Labetolol & Clcr 30-50 ml/perc: maximum $160 \mathrm{mg} / \mathrm{nap}$; Clcr 10-30 ml/perc: maximum $80 \mathrm{mg} / \mathrm{nap}$ \\
\hline \multicolumn{2}{|l|}{$\begin{array}{l}\text { Kalciumantagonista } \\
\text { (dibidropividintipus) }\end{array}$} \\
\hline Barnidipin & Clcr $<50 \mathrm{ml} /$ perc: kontraindikált. \\
\hline \multicolumn{2}{|r|}{ - } \\
\hline Digitálisz & $\begin{array}{l}\text { Clcr } 10-50 \mathrm{ml} / \text { perc: a kezdő dózis } 50 \%-k a l \text { való csökkentése, majd } 0,125 \mathrm{mg} / \mathrm{nap} \text {. Ezt követően a dózis a } \\
\text { klinikai tünetek alapján módosítandó. }\end{array}$ \\
\hline \multicolumn{2}{|l|}{$D M A R D-o k$} \\
\hline Anakinra & Clcr $<30 \mathrm{ml} /$ perc: kontraindikált. \\
\hline Metotrexát & Clcr $40-70 \mathrm{ml} /$ perc: a normáldózis $50 \%$-a; $\mathrm{Clcr}<40 \mathrm{ml} /$ perc: a dozírozás a plazmakoncentrációra alapozott. \\
\hline \multicolumn{2}{|l|}{ Köszvényellenes szerek } \\
\hline Allopurinol & Clcr $50-80 \mathrm{ml} /$ perc: $300 \mathrm{mg} / \mathrm{nap}$; Clcr $30-50 \mathrm{ml} /$ perc: $200 \mathrm{mg} / \mathrm{nap}$; Clcr 10-30 ml/perc: $100 \mathrm{mg} / \mathrm{nap}$ \\
\hline Benzbromaron & Clcr $<30 \mathrm{ml} /$ perc: kontraindikált. \\
\hline Kolchicin & Clcr $10-50 \mathrm{ml} /$ perc: $0,5 \mathrm{mg} / \mathrm{nap}$. \\
\hline $\begin{array}{l}\mathrm{H}_{2} \text {-receptor-antagoni } \\
\text { Nizatidin; cimetidin; } \\
\text { famotidin; ranitidin }\end{array}$ & Clcr 10-30 ml/perc: a normáldózis 50\%-a naponta $1 \times$. \\
\hline \multicolumn{2}{|c|}{$\begin{array}{l}\text { Hipnotikumok, szedatívu- } \\
\text { mok, anxiolitikumok, } \\
\text { antipszichotikumok }\end{array}$} \\
\hline Riszperidon & Clcr $10-50 \mathrm{ml} /$ perc: a normáldózis $50 \%$-a vagy a normáldózis dupla terápiás időintervallumokban. \\
\hline
\end{tabular}

\section{Centrális támadáspontú}

izomvelaxánsok

Baklofén

Clcr 10-50 ml/perc: kezdő dózis 5 mg naponta $1 \times$, majd a hatás/mellékhatásokra alapozva.

Tizanidin

Clcr 10-30 ml/perc: kezdő dózis 2 mg naponta l×, majd lassú dózisemelés a hatás/mellékhatás alapján. A végén a dózisfrekvencia fokozása lehetséges. NSAID-ok Az összes NSAID esetén: Clcr<30 ml/perc: alkalmazásuk mérlegelendő, ha krónikus alkalmazás szükséges.
A terápia megkezdése elótt, majd azt követően egy hét múlva a vesefunkció ellenőrzése szükséges.

Opioidok

Morfin

Clcr 10-50 ml/perc: a terápia a hatás/mellékhatás alapján. A M6G akkumulációja előfordulhat.

Tramadol

Clcr 10-30 ml/perc: a dózisfrekvencia csökkentése, 2-3× naponta, a retard készítmények maximális dózisa 200 $\mathrm{mg} / \mathrm{nap}$.

Tuberkulózis elleni szerek

Etambutol

Clcr 10-50 ml/perc: a normáldózis 50\%-a.

Nootrop szerek

Piracetám

Clcr 30-50 ml/perc: a normáldózis 50\%-a; Clcr 10-30 ml/perc: a normáldózis 25\%-a.

Xantinderivátumok

Pentoxifillin

Clcr 30-50 ml/perc: $400 \mathrm{mg}$ naponta $2 \times$; Clcr 10-30 ml/perc: $400 \mathrm{mg}$ naponta $1 \times$.

ACE = angiotenzinkonvertáló enzim; Clcr = kreatininclearance; DMARD = betegségmódosító antireumatikus készítmény; M6G = morfin-6-glukuronid; NSAID = nemszteroid gyulladáscsökkentő 


\section{Az öregedés folyamatainak hatása a farmakodinámiára}

Az időskor hatását számos receptor aktivitására, illetve expressziójára vonatkozóan tanulmányozták, azonban ezek hatása a farmakodinámiára nincs teljesen felderítve. A verapamil hatása az EKG PR-szakaszára csökken időskorban, mivel azonban az elimináció is csökken, a terápiás hatékonyság nem változik. Érdekes, hogy míg az amlodipinclearance csökken időskorban a fiatalokhoz képest (19 \pm 5 versus 7 1/ó), a vérnyomáscsökkentő hatása az azonos plazmakoncentrációknak megmarad [19]. Az öregedés a $\beta$-adrenerg receptorok downregulációját okozza. Ez magyarázhatja mind a $\beta$-agonisták csökkent bronchodilatator aktivitását idősekben, mind a késői életkorban kialakuló asztma okát [20]. A szív-ß-1receptorok mennyisége hozzávetőleg 30\%-kal csökken, így az izoprenalin hatása a szisztolés kontrakciókra 46\%kal csökken [21]. A ß-blokkolók hatékonysága - úgy tünik - csökken időskorban más antihipertenzívumokhoz képest [22]. A benzodiazepinek farmakodinámiás változása fontos az idősek esetén, mivel ez a gyógyszercsoport nagymértékben felelős az elesésekért, illetve combnyaktörésekért. Az intravénás midazolám szedatív hatása mintegy 50\%-kal csökken az idősek esetén annak ellenére, hogy életkorfüggő farmakokinetikai változások nem mutathatók ki [23].

\section{Az öregedés folyamatainak hatása a klinikumra}

A gyógyszerek kedvezőtlen mellékhatásai az egészségügy kiemelt problémái közé tartoznak. Vannak adatok, hogy a gyógyszermellékhatás következtében történő halálozás tartósan a halálozási listák 4., 6. helyének valamelyikét foglalja el. A kórházi felvételek 5-10\%-a gyógyszertoxicitás miatt történik [24]. Ha ehhez még azt is hozzátesszük, hogy a gyógyszermellékhatások jelentése nem megfelelő (jóval kevesebb, mint amennyi történik), akkor képet kaphatunk a probléma nagyságáról. Ráadásul az idős betegeknél a gyógyszermellékhatások nagyobb valószínúséggel súlyosabbak, mint a fiatalabbaknál észleltek. Mi több, az idősek gyakran fel sem ismerik, illetve nem fordulnak orvoshoz vele [25]. A magasabb életkor nagyobb kockázatot jelent a mellékhatások szempontjából, érdekes módon azonban egyes gyógyszerek esetén ez független a farmakokinetikától vagy az együtt adott gyógyszerektől. Például a NSAID-ok okozta mellékhatások komoly problémává váltak, különösen a $\mathrm{COX}_{2}$-gátlók bevezetése óta, mivel a felső gastrointestinalis vérzések és perforációk száma jelentős mértékben fokozódott az ilyen terápiában részesülő idősek esetében [26]. Mi több, az időskor fokozza a NSAID okozta hypertonia kockázatát, mivel NSAID-kezelés elindítása után 1,7-szeresével fokozódik az antihipertenzív kezelések elindításának szükségessége [27]. Ráadásul az idős, NSAID-kezelésben részesülők között megduplázódik a veseelégtelenek aránya [28]. Idősekben még a ritka gyógyszermellékhatások előfordulása is gyakoribb, mint például a $\mathrm{H}_{2}$-receptor-antagonisták okozta interstitialis nephritis vagy hepatitis [29]. Manapság úgy tünik, hogy az 1 fázisú gyógyszer-metabolizmus (oxidáció, hidroxiláció, N-dealkiláció, N-demetiláció, szulfoxidáció, nitroredukció, hidrolízis) némileg csökken időskorban, míg a 2 fázisú gyógyszer-metabolizmus (konjugáció) nem változik. Hangsúlyozandó, hogy a toxicitás olykor lassan alakul ki. Krónikus gyógyszeradagolás esetén a plazmakoncentráció folyamatosan emelkedik, ami a gyógyszerre jellemző 5-6 plazmafelezési ideig tart, mert ekkor alakul ki az egyenletes (steady-state) plazmakoncentráció. Például egyes benzodiazepinek (diazepám, flurazepám, klórdiazepoxid) plazmafelezési ideje 96 óra is lehet, így a toxicitás tünetei napokkal vagy akár 1-3 héttel a terápia megkezdése után jelentkeznek. Ez is hozzájárul ahhoz, hogy a betegek a jelentkező tüneteket már nem hozzák összefüggésbe a hetek óta tartó terápiával, mi több, gyakran az orvosok sem gondolnak erre.

Fontos megérteni, hogy alig van evidencia az esendő (frail) állapotú betegek gyógyszeres kezelésével kapcsolatban, mivel ezek a betegek nem kerülnek be a klinikai vizsgálatokba. A geriátriai osztályok egyik legfontosabb feladata ilyen vizsgálatok szervezése és végzése lenne. Szerencsére az esendő állapotú betegek terápiás problémái is megjelennek már a szakirodalomban. A probléma lényege, hogy az esendő állapotú betegek sokkal több gyógyszert kapnak, mint a jobb állapotú betegek, ugyanakkor nincsenek terápiás ajánlások az ilyen idős betegek kezelésére. Egy vizsgálatban azt találták, hogy a polypragmasia (5 vagy annál több gyógyszer egyidejü adása) az esendó állapotú betegek között 64,7\% volt, szemben a jobb állapotú betegek $27,2 \%$-os arányával [30]. A sürgősségi ellátás során az esendő állapotú betegek sokkal több gyógyszert kapnak egyidejûleg, mint a nem esendő állapotú idős betegek $(9,8 \pm 4,3$ versus $4,4 \pm 3,3)$, illetve több olyan gyógyszert kapnak, amely fokozza az elesések kockázatát $(3,4 \pm 2,2$ versus $1,6 \pm 1,5)$ [31]. A polypragmasia komoly veszélyekkel jár. Az adatok azt mutatják, hogy a 65 évnél idósebbek átlag 2-9 különféle gyógyszert szednek, 57\%-uk 5-vagy többfélét és $12 \%$-uk 10vagy többfélét [32]. Újabb adatok azt bizonyítják, hogy a fokozott gyógyszerelés hozzájárul ahhoz, hogy a 'prefrail' betegek esendő állapotúvá váljanak, illetve szerepet játszhat a bekövetkező halálozásukban is. A jó állapotú (fitt) idős betegek esetén minden új gyógyszer hozzáadása a meglévő terápiához 22\%-kal fokozta a halálozás kockázatát [33]. Kevés olyan klinikai vizsgálat van, amelyet 'frail' betegek bevonásával végeztek. A HYpertension in the Very Elderly Trial (HYVET) vizsgálat azt igazolta, hogy az antihipertenzív terápia jótékony hatása független az esendóség állapotától [34]. A Systolic blood PRessure INtervention Trial (SPRINT) vizsgálat szerint 75 éves vagy idősebb betegek esetén, ha a szisztolés vérnyomást a célértékre $(\leq 120 \mathrm{Hgmm} ; \mathrm{n}=1317)$ viszik le, akkor a kontrollcsoporttal szemben (140 Hgmm; $\mathrm{n}=$ 
1319) szignifikáns mértékben csökken a fatális, illetve nem fatális cardiovascularis események száma (HR 0,66 [95\% CI 0,51-0,85]), és csökken a bármilyen okból bekövetkező (all-cause) halálozás (HR 0,67 [95\% CI 0,49$0,91])[35]$.

\section{Az idős betegek terápiás adherenciája}

Az öregedés során előtérbe kerülnek a kognitív változások, amelyek az egyszerü feledékenységtől a dementiáig terjedhetnek. Mindezek befolyásolhatják az orális terápiák eredményét. Így a terápiaadherencia a geriátriai betegek kezelésének fontos tényezője. Egy vizsgálatban 316, hatvanöt évnél idősebb beteg vett részt, aki otthonában részesült gyógyszeres terápiában. A tabletták megszámolása azt mutatta, hogy a betegek $34,7 \%$-a esetén, illetve a megszámolt különféle gyógyszerek 47,5\%-a esetén kimutatható volt a terápiás nonadherencia [36]. Egy másik tanulmány azt igazolta, hogy a betegek $51 \%$-a szedett olyan gyógyszert is, amely nem szerepelt a zárójelentésein, illetve $29 \%$-uk nem minden gyógyszert szedett, amelyet elöírtak neki, valamint a betegek $20 \%$-a maga módosította egyes gyógyszerek elóírt dózisát [37]. Egy metaanalízis szerint az adherencia mértéke 4,5-100\% (átlag 75,2\%), az adherencia mérésére használt módszertől függően [38]. A WHO adatai szerint az adherencia hiánya kifejezettebb a fejlődő országokban, mint a világ fejlettebb részén. Ez arra utal, hogy ez a terület jelentős tartalékokat rejt magában a szegényebb országok terápiás eredményeinek javításában. A terápiás adherencia hiánya a fejlett országokban is komoly probléma. Az amerikai adatok szerint a nonadherencia évente 100 milliárd USD költséget okoz az Egyesült Államok egészségügyi rendszerének.
Aki egy idős beteg kezelése során észleli, hogy a gyógyszerszedés nem az elóírások szerint történik, mindig tisztázza, hogy nincs-e a betegnek nyelési problémája. A nyelés számos izom koordinált múködését igényli. A beidegzés öregedésből adódó változása vagy némely betegség (például Parkinson-kór) nyelési problémát okozhat. Ápolási otthonban élő idős embereknél az ott élők 50\%-ánál nyelési nehezítettséget észleltek [39]. Egy másik tanulmány szerint az 55 évnél idősebbek 22\%-ánál észlelhető dysphagia [40].

\section{A potenciálisan veszélyes gyógyszerek időskorban}

Azért, hogy fokozzák az idős betegek gyógyszerterápiájának biztonságát, meghatározták a potenciálisan inadekvát medikáció (PIM = potentially inappropriate medication) kritériumait [41]. Eredetileg egy amerikai geriáter, Mark H. Beers közölte ezeket a kritériumokat, amelyeket időnként megújítanak (1997, 2003, 2012, 2015). Az eredeti, 1991-es közlemény (mi a 2015-ben közölt legutolsó változatot citáljuk) egy 11 tagból álló multidiszciplináris szakértői panel konszenzusán alapult. A jelenlegi lista táblázatokban közli azokat a gyógyszereket, amelyeket az idősek esetén kerülni kell, vagy dózisukat a beteg vesefunkciója alapján módosítani szükséges, illetve amelyekkel olyan gyógyszer-interakciókat dokumentáltak, amelyek az idősek számára veszélyesek. A 2018-as megújítás folyamatban van. Ezek a táblázatok, amelyek rendkívül hasznosak minden, idős beteget kezelő orvos számára, az interneten könnyen megkereshetők (Beers-criteria).

A 2. táblázatban foglaltuk össze azokat a gyógyszereket, amelyek időskorban a legtöbb problémát okozzák.

2. táblázat | Időskorban gyakori vagy súlyos mellékhatásokat okozó készítmények

\begin{tabular}{|c|c|c|}
\hline Gyógyszer (csoport) & Mellékhatás & Teendő \\
\hline Barbiturátok & Számos problémát okoz & Ne alkalmazzuk \\
\hline Benzodiazepinek & Napközbeni álmosság & Dózisfelezés \\
\hline Digoxin & Csökkent clearance & $\begin{array}{l}\text { Dóziscsökkentés (sinusrhythmusban ritkán } \\
\text { szüikséges) }\end{array}$ \\
\hline Heparin & Vérzés & Ne használjuk 48 óránál tovább \\
\hline Opiátok & Fokozott érzékenység & Dóziscsökkentés \\
\hline Orális antidiabetikumok & Nocturnalis hypoglykaemia & Rövid hatástartamú szerek használata \\
\hline Parkinson-kór elleni szerek & Antikolinerg hatás, konfúzió, posturalis hypotensio & Terápia kórházi osztály ellenőrzése mellett \\
\hline Fenotiazinok & Extrapiramidális tünetek & Ha lehet, ne használjuk \\
\hline Fenilbutazon & Számos problémát okoz, csontvelő-aplasia & $\begin{array}{l}\text { Rövid idejü használat, biztonságosabb alternatív } \\
\text { készítmény }\end{array}$ \\
\hline Tetraciklinek & Veseelégtelenség & Alternatív készítmény használata \\
\hline Tiroxin & Myocardialis ischaemia & Terápia kórházi osztály ellenőrzése mellett \\
\hline Triciklusos antidepresszánsok & Antikolinerg hatás, konfúzió, posturalis hypotensio & Dózisfelezés \\
\hline Vérnyomáscsökkentők & Posturalis hypotensio & Kerülendő: betanidin, guanetidin, debrizokvin \\
\hline Warfarin & Fokozott érzékenység & Dóziscsökkentés \\
\hline
\end{tabular}


3. táblázat | Gyakori gyógyszer-interakciók időskorban

\begin{tabular}{lll}
\hline Gyógyszer & Interakció & Hatás \\
\hline ACE-gátlók & NSAID-ok, coxibok, káliumvesztést nem okozó diuretikumok & Csökkent vesefunkció, hyperkalaemia \\
\hline Antidepresszánsok & Enziminduktorok* & Csökkent hatékonyság \\
\hline Béta-receptor-gátlók & $\begin{array}{l}\text { Antidiabetikumok } \\
\text { Fluoxetin, paroxetin (különösen metoprolollal vagy propranolollal } \\
\text { kombinálva) }\end{array}$ & $\begin{array}{l}\text { Elfedik a hypoglykaemia tüneteit } \\
\text { Bradycardia }\end{array}$ \\
\hline Kortikoszteroidok (orális) & $\begin{array}{l}\text { NSAID-ok } \\
\text { Enziminduktorok* }\end{array}$ & $\begin{array}{l}\text { Gastroduodenalis fekély } \\
\text { Csökkent kortikoszteroidhatás }\end{array}$ \\
\hline Digoxin & NSAID-ok, diuretikumok, kinidin, verapamil, diltiazem, & Digoxintoxicitás \\
\hline Fluorokinolonok & amiodaron & Csökkent biohasznosulás \\
\hline Levodopa & Vas & Csökkent biohasznosulás \\
\hline Lítium & NSAID-ok, tiazid, diuretikumok, antipszichotikumok & Lítiumtoxicitás \\
\hline Fenitoin & Enziminduktorok* $*$ & Fokozott toxicitás \\
\hline Szulfonilurea antidiabetikumok & SSRI-k, klóramfenikol, VKA-k, fenilbutazon & Hypoglykaemia \\
\hline SSRI-k & Diuretikumok, NSAID-ok & Hyponatraemia, gyomorvérzés \\
\hline Tetraciklin & Antacidok, vas & Csökkent biohasznosulás \\
\hline Vérnyomáscsökkentók & $\begin{array}{l}\text { Vasodilatatorok, TCA-k, antipszichotikumok } \\
\text { NSAID-ok }\end{array}$ & $\begin{array}{l}\text { Fokozott antihipertenzív hatás } \\
\text { Csökkent antihipertenzív hatás }\end{array}$ \\
\hline VKA & Acetilszalicilsav, NSAID-ok, metronidazol, mikonazol és egyéb & Vérzés \\
\hline & azol típusú gyógyszerek & \\
\hline
\end{tabular}

ACE = angiotenzinkonvertáló enzim; NSAID = nemszteroid gyulladáscsökkentő; SSRI = szelektív szerotoninvisszavétel-gátló; TCA = triciklusos antidepresszáns; VKA = vitamin-K-antagonista

*Karbamazepin, rifampicin, fenobarbitál, fenitoin, orbáncfú

**Verapamil, diltiazem, amiodaron, flukonazol, mikonazol, ketokonazol, eritromicin, klaritromicin, szulfonamidok, cimetidin, ciprofloxacin és grépfrútlé

A gyógyszer-interakcióknak alapvetően két típusát különböztetik meg. Az egyik alapja a metabolizmus, a másik alapja a gyógyszertranszport. Mindkét folyamat gátlása vagy indukciója klinikai következményekkel jár. Az együtt adott gyógyszerek esetén az interakciók valószínúsége fokozott, ha az úgynevezett terápiás ablak szúk, illetve ha a dózis-hatás összefüggés meredek. További gyógyszer-interakció jöhet létre a gyógyszerek hatáshelyén, ha a gyógyszerek kötőhelye azonos. Ilyenkor a hatás szempontjából szinergizmus vagy antagonizmus egyaránt létrejöhet. Az egyéb interakciós lehetőségek, mint például a HNMT (hisztamin-N-metil-transzferáz) vagy a DAO (diamin-oxidáz), melyek a hisztamin fó metabolizáló enzimei, elsősorban az együtt adott gyógyszerek esetén kialakuló allergia szempontjából fontosak. Az interakciók potenciálisak, ami azt jelenti, hogy nem szükségszerúek, azaz van, akinél két gyógyszer egyidejü adása tüneteket okoz, és van, akinél nem. A potenciális interakciók előfordulása sokkal gyakoribb, mint a ténylegesen tünetet okozóké. Egy tanulmányban 674 geriátriai járó beteget vizsgáltak, akik legalább két különféle gyógyszert kaptak egyidejúleg. A vizsgálat szerint 300 beteg esetén $(44,5 \%)$ összesen 398 potenciális interakciót találtak. Legalább egy mellékhatást vagy nem megfelelő hatékonyságú kezelést csak 172 beteg esetén $(25,5 \%)$ észleltek [42]. Idős betegek ( $\geq 70$ év) esetén a ténylege- sen megtapasztalt gyógyszer-interakciók prevalenciája 1992 és 2005 között növekedett, 10,5\%-ról 19,2\%-ra, ezen belül az életveszélyes interakciók száma 1,5\%-ról 2,9\%-ra emelkedett [43].

A 3. táblázatban az idôseknél észlelt leggyakoribb gyógyszer-interakciókat mutatjuk be.

Az orbáncfü a Kárpát-medencében őshonos növény. A középkorban „ördögűzőnek” tekintették, mivel hat az álmatlanság ellen, javítja a közérzetet, enyhe antidepreszszáns és nyugtató. Manapság az orbáncfúkivonat széles körben használt, recept nélkül kapható készítmény, mi több, saláták, likőrök ízesítésére is használják. Mint gyógynövényt, sokan ártalmatlannak gondolják, pedig ez korántsem igaz. Festékanyaga hipericint tartalmaz, amely fényérzékenyítő hatású. Napfény hatására a szedőkben viszketés, bőrgyulladás, sốt hólyagos bőrkiütés jelentkezhet. Mi több, az orbáncfü megváltoztathatja egyes gyógyszerek kinetikáját és így azok hatékonyságát is - ezeket mutatja be a 4. táblázat [44].

\section{Következtetés}

Manapság már az időskort is több korcsoportra osztják, így beszélnek korai öregkorról (65-74 év), középső öregkorról (75-84 év), illetve késói öregkorról ( $\geq 85$ év). Jelenleg nincs adat arra, hogy ez a három korcsoport a 
4. táblázat |Az orbáncfü gyakori interakciói más gyógyszerekkel [44]

\begin{tabular}{ll}
\hline Gyógyszer & Orbáncfüvel történő interakció \\
\hline Amitriptilin & $\begin{array}{l}\text { A steady-state plazmakoncentráció } \\
22 \% \text {-kal csökken. }\end{array}$ \\
Ciklosporin & A steady-state plazmakoncentráció \\
& $52 \%$-kal csökken. \\
Digoxin & A steady-state plazmakoncentráció \\
& $25 \%$-kal csökken. \\
Szimvasztatin & Az AUC 50\%-kal csökken. \\
Takrolimusz & A steady-state plazmakoncentráció \\
& $80 \%$-kal csökken. \\
Teofillin & A steady-state plazmakoncentráció \\
& $50 \%$-kal csökken. \\
Vitamin-K-antagonisták & Az INR 50\%-kal csökken. \\
\hline
\end{tabular}

AUC = koncentráció-idő görbe alatti terület; INR = nemzetközi normalizált ráta

terápia szempontjából különbözik-e egymástól, és ha igen, miben. Arra azonban van evidencia, hogy a középső és a késői öregkorban a fiziológiás változások már egyértelműen kimutathatók. Az idős betegek másik csoportosítása a fitt vagy esendő csoportba történő besorolás, ez azonban független az életkortól. Egy tanulmány szerint a 77-79 éves korcsoportban 57,6\%-ban, a 80-84 éves korcsoportban 61,4\%-ban, illetve a 85 évnél idősebbek esetén 79,9\%-ban észleltek problémát az otthoni gyógyszerelés betartásában [45]. Egy másik tanulmányban hasonló korcsoportba tartozó (75-97 éves) betegeket kérdeztek arról, hogy mi segítené a gyógyszerelés otthoni betartását. A válaszok azt mutatták, hogy az egyszerü terápiás séma, a gyógyszerek felismerését segítő vizuális és taktilis támogatás javítaná a terápia betartását. A geriátriai farmakoterápia fejlődéséhez elengedhetetlen, hogy az időskor fiziológiás változásait már a gyógyszerfejlesztés és -kiszerelés során figyelembe vegyék.

Anyagi támogatás: A szerzők a közlemény megírásához anyagi támogatásban nem részesültek.

Szerzői munkamegosztás: T. A.: A téma felvetése, feldolgozása, a közlemény megírása. D. D.: Szakirodalmi anyag összegyưjjtése, a közlemény kiegészítése, formattálása. A cikk végleges változatát mindkét szerző elolvasta és jóváhagyta.

\section{Érdekeltségek: A szerzőknek nincsenek érdekeltségeik.}

\section{Irodalom}

[1] Papa S. Mitochondrial oxidative phosphorylation changes in the lifespan. Molecular aspects and physiopathological implications. Biochim Biophys Acta 1996; 1276: 87-105.

[2] Kirkwood TB, Austad SN. Why do we age? Nature (Lond). 2000; 408: 233-238.
[3] Park WY, Hwang CI, Kang MJ, et al. Gene profile of replicative senescence is different from progeria or elderly donor. Biochem Biophys Res Commun. 2001; 282: 934-939.

[4] Sohal RS, Weindruch R. Oxidative stress, caloric restriction and aging. Science 1996; 273: 59-63.

[5] Feldman M. The mature stomach. Still pumping out acid? JAMA 1997; 278: 681-682.

[6] Doherty MM, Charman WN. The mucosa of the small intestine: how clinically relevant as an organ of drug metabolism? Clin Pharmacokinet. 2002; 41: 235- 253.

[7] Grandison MK, Boudinot FD. Age-related changes in protein binding of drugs: implications for therapy. Clin Pharmacokinet. 2000; 38: 271-290.

[8] Benet LZ, Hoener BA. Changes in plasma protein binding have little clinical relevance. Clin Pharmacol Ther. 2002; 71: 115121.

[9] Beaufrere B, Morio B. Fat and protein redistribution with aging: metabolic considerations. Eur J Clin Nutr. 2000; 54(Suppl 3): S48-S53.

[10] Schmucker DL, Woodhouse KW, Wang RK, et al. Effects of age and gender on in vitro properties of human liver microsomal monooxygenases. Clin Pharmacol Ther. 1990; 48: 365-374.

[11] Tanaka E. In vivo age-related changes in hepatic drug-oxidizing capacity in humans. J Clin Pharm Ther. 1998; 23: 247-255.

[12] Sotaniemi EA, Arranto AJ, Pelkonen O, et al. Age and cytochrome P450-linked drug metabolism in humans: an analysis of 226 subjects with equal histopathological conditions. Clin Pharmacol Ther. 1997; 61: 331-339.

[13] Lipman RD, Dallal GE, Bronson RT. Lesion biomarkers of aging in the B6C3Fl hybrid mice. J Gerontol A Biol Sci Med Sci. 1999; 54: B466-B477.

[14] Fliser D, Bischoff I, Hanses A. Renal handling of drugs in the healthy elderly. Creatinine clearance underestimates renal function and pharmacokinetics remain virtually unchanged. Eur J Clin Pharmacol. 1999; 55: 205-211.

[15] Peters AM, Henderson BL, Lui D. Indexed glomerular filtration rate as a function of age and body size. Clin Sci (Lond). 2000; 98: 439-444.

[16] Sanaka M, Takano K, Shimakura K, et al. Serum albumin for estimating creatinine clearance in the elderly with muscle atrophy. Nephron 1996; 73: 137-144.

[17] Mühlberg W, Platt D. Age-dependent changes of the kidneys: pharmacological implications. Gerontology 1999; 45: 243-253.

[18] Miletić D, Fuckar Z, Sustić A, et al. Sonographic measurement of absolute and relative renal length in adults. J Clin Ultrasound 1998; 26: 185-189.

[19] Abernethy DR. An overview of the pharmacokinetics and pharmacodynamics of amlodipine in elderly persons with systemic hypertension. Am J Cardiol. 1994; 73: 10A-17A.

[20] Connolly MJ, Crowley JJ, Charan NB, et al. Impaired bronchodilator response to albuterol in healthy elderly men and women. Chest 1995; 108: 401-406.

[21] White M, Roden R, Minobe W, et al. Age-related changes in beta-adrenergic neuroeffector systems in the human heart. Circulation 1994; 90: 1225-1238.

[22] Mulrow C, Lau J, Cornell J, et al. Pharmacotherapy for hypertension in the elderly. Cochrane Database Syst Rev 2000; (4): CD000028.

[23] Albrecht S, Ihmsen H, Hering W, et al. The effect of age on the pharmacokinetics and pharmacodynamics of midazolam. Clin Pharmacol Ther. 1999; 65: 630-639.

[24] Mjorndal T, Boman MD, Hagg S, et al. Adverse drug reactions as a cause for admissions to a department of internal medicine. Pharmacoepidemiol Drug Saf. 2002; 11: 65-72.

[25] Mannesse CK, Derkx FH, de Ridder MA, et al. Do older hospital patients recognize adverse drug reactions? Age Ageing 2000; 29: 79-81. 
[26] Hernandez-Diaz S, Rodriguez LA. Association between nonsteroidal antiinflammatory drugs and upper gastrointestinal tract bleeding/perforation: an overview of epidemiologic studies published in the 1990s. Arch Intern Med. 2000; 160: 2093-2099.

[27] Johnson AG. NSAIDs and blood pressure. Clinical importance for older patients. Drugs Aging 1998; 12: 17-27.

[28] Field TS, Gurwitz JH, Glynn RJ, et al. The renal effects of nonsteroidal anti-inflammatory drugs in older people: findings from the established populations for epidemiological studies of the elderly. J Am Geriatr Soc. 1999; 47: 507-511.

[29] Fisher AA, LeCouteur DG. Nephrotoxicity and hepatotoxicity of histamine $\mathrm{H}_{2}$ receptor antagonists. Drug Safety 2001; 24: 3957.

[30] Gnjidic D, Hilmer SN, Blyth FM, et al. High-risk prescribing and incidence of frailty among older community-dwelling men Clin Pharmacol Ther. 2012; 91: 521-528.

[31] Bennett A, Gnjidic D, Gillett M, et al. Prevalence and impact of fall-risk-increasing drugs, polypharmacy, and drug-drug interactions in robust versus frail hospitalised falls patients: a prospective cohort study. Drugs Aging 2014; 31: 225-232.

[32] Hajjar ER, Cafiero AC, Hanlon JT. Polypharmacy in elderly patients. Am J Geriatr Pharmacother. 2007; 5: 345-351.

[33] Jamsen KM, Bell JS, Hilmer SN, et al. Effects of changes in number of medications and drug burden index exposure on transitions between frailty states and death: the Concord Health and Ageing in Men Project Cohort Study. J Am Geriatr Soc. 2016; 64: 89-95.

[34] Warwick J, Falaschetti E, Rockwood K, et al. No evidence that frailty modifies the positive impact of antihypertensive treatment in very elderly people: an investigation of the impact of frailty upon treatment effect in the HYpertension in the Very Elderly Trial (HYVET) study, a double-blind, placebo-controlled study of antihypertensives in people with hypertension aged 80 and over. BMC Med. 2015; 13: 78

[35] Williamson JD, Supiano MA, Applegate WB, et al. Intensive ps standard blood pressure control and cardiovascular disease out- comes in adults aged $\geq 75$ years: a randomized clinical trial. JAMA 2016; 315: 2673-2682.

[36] Vik SA, Maxwell CJ, Hogan DB, et al. Assessing medication adherence among older persons in community settings. Can J Clin Pharmacol. 2005; 12: el52-el64.

[37] Delafuente JC. Understanding and preventing drug interactions in elderly patients. Crit Rev Oncol Hematol. 2003; 48: 133143.

[38] George J, Elliott RA, Stewart DC. A systematic review of intervenions to improve medication taking in elderly patients prescribed multiple medications. Drugs Aging 2008; 25: 307-324.

[39] Nilsson H, Ekberg O, Olsson R, et al. Quantitative aspects of swallowing in an elderly nondysphagic population. Dysphagia 1996; 11: 180-184.

[40] Hind JA, Nicosia MA, Roecker EB, et al. Comparison of effortful and noneffortful swallows in healthy middle-aged and older adults. Arch Phys Med Rehabil. 2001; 82: 1661-1665.

[41] American Geriatrics Society 2015 Beers Criteria Update Expert Panel. American Geriatrics Society 2015 updated Beers criteria for potentially inappropriate medication use in older adults. J Am Geriatr Soc. 2015; 63: 2227-2246.

[42] Tulner LR, Frankfort SV, Gijsen GJ, et al. Drug-drug interactions in a geriatric outpatient cohort: prevalence and relevance. Drugs Aging 2008; 25: 343-355.

[43] Becker ML, Visser LE, van Gelder T, et al. Increasing exposure to drug-drug interactions between 1992 and 2005 in people aged $\geq 55$ years. Drugs Aging 2008; $25: 145-152$.

[44] Huang SM, Hall SD, Watkins P, et al. Drug interactions with herbal products and grapefruit juice: a conference report. Clin Pharmacol Ther. 2004; 75: 1-12.

[45] Beckman AGK, Parker MG, Thorslund M. Can elderly people take their medicines? Patient Educ Couns. 2005; 59: 186-191.

(Telekes András dr., Salgótarján, Füleki út 54-56., 3100 e-mail: prof.andras.telekes@gmail.com)

\section{Az Orvosi Hetilap 2019, 160, 723. oldalán (18. szám) megjelent OH-Kvízre egy helyes megfejtés érkezett.}

A beküldő: Dr. Janik Leonárd (Budapest).

A nyertesnek szívből gratulálunk.

Nyereményét - egy, az Akadémiai Kiadó webáruházában kedvezményes vásárlásra jogosító kupont - e-mailen küldjük el. 